\title{
Model for Industrial Site Selection towards a More Sustainable Dammam Metropolitan Area: Experts-Based Analytic Hierarchy Process
}

\author{
Faez S. Al-Shihri and Dano U. Lawal \\ Department of Urban and Regional Planning, College of Architecture \& Planning, University of \\ Dammam, P.O. Box: 2397, Dammam 31451, Saudi Arabia \\ fshihri@uod.edu.sa
}

\begin{abstract}
Industrial site selection is the process of choosing the most suitable location(s) that meets the desired requirements set by the selection criteria. Siting an industry is a major long-term investment. In this sense, selection of the most suitable location is imperative in satisfying the social, economic, environmental, and sustainability requirements. Identifying the most suitable site(s) with desired requirements defined by the selection criteria is basically one of the key objectives of industrial site selection. The majority of the data used by managers and decision makers in industrial site selection are geographically related, which denotes the industrial site selection process to be a spatial decision issue. Therefore, this study employed Analytic Hierarchy Process (AHP) model to evaluate the location suitability of the existing industries Dammam Metropolitan Area (DMA) based on a number of decision criteria used in selecting the most suitable industrial sites. Priority weights were calculated after ranking each criterion using the Saaty's 9 point scale of preference by the experts. Weights were calculated and further normalized through the AHP. The findings of the survey have been used to evaluate the existing and approved industrial sites in DMA. The study have reached an important conclusion and recommendations with regards to the existing and approved industrial sites in DMA.
\end{abstract}

Keywords: Suitability analysis, industrial site selection, Analytic Hierarchy Process (AHP), urban sustainability, Dammam Metropolitan Area.

\section{Introduction}

Industrial development is a very critical aspect of the urban morphology. Industries provide employment and economic opportunities; but at the same time, it contributes to environmental pollutions. Long ago, site selection for industrial development was based virtually on technical and socio-economic criteria [1]. Nowadays site selection criteria must satisfy the environmental aspects as well. The process of industrial site selection signifies a complex multi-criteria analysis including a complex collection of decision elements relating to social, economic, environmental, technical, and political factors that may end in conflicting objectives ${ }^{[2-4]}$. Moreover, risk management is a crucial element in the site selection process. Application of risk management principles in choosing a new site for industrial development is one of the most important issue responsible for the success or failure of any industry ${ }^{[1]}$. To lessen the risks, stakeholders should first be involved in decision making process of the site selection.

Site selection for industrial development is therefore a serious point in the startup process, expansion or change of the location of industrial systems of all kinds. One of the key objectives in industrial site selection is searching the most suitable site with chosen conditions defined by the selection criteria. Decision making on industrial sites location is a primary component of strategic and logistical 
decision-making through studying a wide series of conflicting decision criteria so as to regulate socioeconomic benefits as well as environmental sustainability. Hence, the selection criteria must meet a number of social and environmental components prescribed by the laws and government guidelines ${ }^{[1]}$. Site selection refers to the process of finding the most suitable sites for establishing a specific project depending on socioeconomic and environmental criteria [5]. Currently, some developing countries and large cities take the preliminary step of forming certain regions for industrial development, purposely to segregate them from densely populated areas. Selection criteria must also meet a number of environmental elements enforced by law and government regulations ${ }^{[1]}$.

In Dammam Metropolitan Areas (DMA), there are basically two industrial zones (Industrial Zone 1 and 2); and all the existing industries in these zones are mainly light and medium scale industries, with very little elements of the heavy industries.

Therefore in this study, Analytical Hierarchy Process (AHP) is used in evaluating the location of the existing industries in Dammam Metropolitan Area. This is by examining the industrial site selection criteria such as highways, railway lines, seaport, airport, landfill site, as well as the existing industries, which are all applicable to the all available types of industries in DMA (light and medium scale industries). AHP is used in calculating the priority weight of each individual criterion so as to guide decision making process. The AHP methodology has been adapted in various fields including engineering, military, management, manufacturing, politics, social, sports and even at the individual level ${ }^{[6-14]}$. It has been applied in areas including flood management, business administration, cost-benefit analysis, future planning, resolution of conflicts, determining requirements, allocating resources, measuring performance, designing systems and ensuring system stability ${ }^{[15]}$. Much work and literature available on the application of AHP in geoengineering are devoted to the development of relative weights of influential factors and incorporation of the weights into GIS system. As for example, ${ }^{[16]}$ derived relative weights of influential factors affecting urban (Lanzhou city, China) geo-environment using AHP, and the suitability potentials of urban land use were evaluated and assessed using GIS. Similarly, Ayalew et al. (2004) ${ }^{[17]}$ used pairwise comparisons to arrive at the relative weights of landslide controlling factors, and used GIS to prepare landslide hazard assessment map for Tsugawa area of Agano River, Niigata Prefecture, Japan. Komac (2006) employed multivariate statistical analysis and concluded that the use of the AHP method gives a means to define the factor weights in the linear landslide susceptibility model ${ }^{[18]}$. In the aforementioned previous studies, the AHP mathematical model was used in generating relative important weights to modeled future events. While in this study the method is applied to evaluate the existing industries in DMA so as to assess their locations in terms of suitability.

\section{Study Area}

The Dammam city is formed by the neighboring conurbations of Dammam, Khobar, Dhahran and the emerging areas of Aziziyah and Half Moon situated in the southern part of Khoper. Larger Dammam comprises of Dammam Metropolitan Area (DMA) and the bordering municipalities of Qatif, Safwa and Ras-Tanura. DMA has the total area of approximately 380,000 ha, housing roughly 1.8 million residents. The Kingdom's economy mainly depends on oil exploration, oil extraction and oil processing along with exportation of the petroleum and its products. The Kingdom's Eastern Province is 
basically the heart of Saudi Arabian oil production. Thus, the economy as well as the physical development of DMA is largely influenced by the petroleum industry. Figure 1 shows the components of DMA and its external connections.

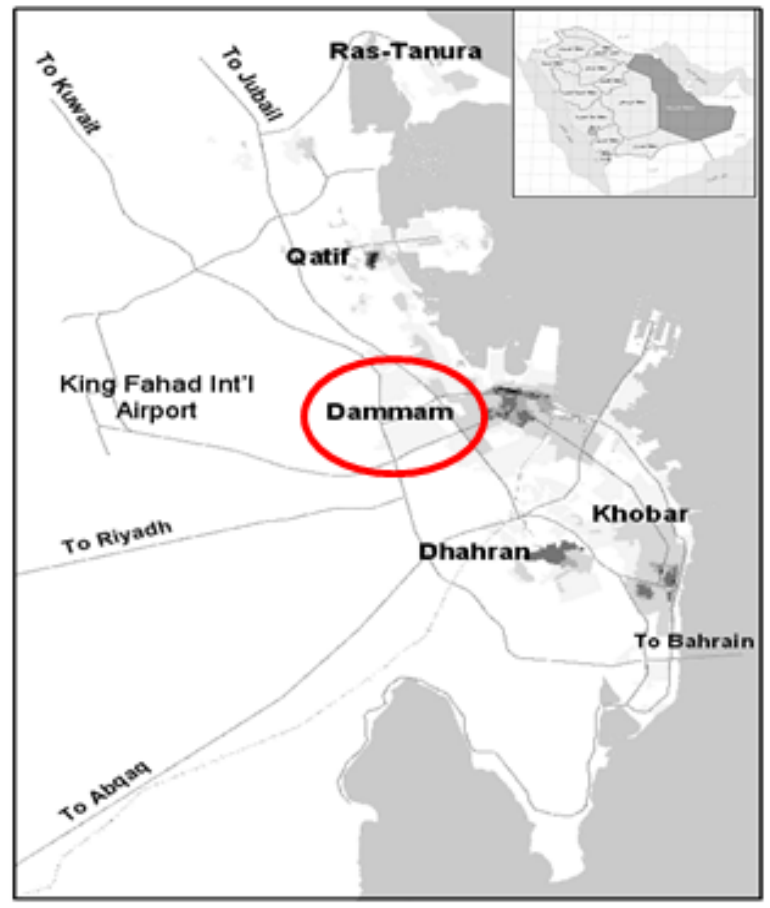

Fig. 1. Dammam Metropolitan Area: Components and External Connections ${ }^{[19]}$.

\section{Process of Site Selection}

Traditionally, selection of suitable site for development purposes especial identifying suitable sites for industrial development, economic and technical criteria were mainly considered [1]. Nowadays, an advanced assessment is expected. This is by considering a number of environmental requirements in the selection criteria. Industrial site selection process signifies a multifaceted multi-criteria decision analysis involving different range of criteria involving environmental, social, economic, technical, and political elements likely to result in conflicting objectives ${ }^{[2-4]}$. In today's knowledge-based society, the public are considered to be most vital resource when siting any kind of development ${ }^{[20]}$. For instance, proximity to educational institutions, amount of novelties per individual can be one of the fundamental factors to be considered by decision makers. Similarly, controlling risk is necessary in the site selection process, especially in an attempt to identify a new industrial location as it determines the actual success or failure of an investment [1]. Investors need to first be aware of the phases of the site selection process as well as knowing what the key risks are, in order to be included and controlled during each of the phases. Time factor such as proximities to highways, seaports, railway lines, and airports for shipment of industrial products is also one of the most important factors, however sometimes used to be neglected when analyzing the suitability of certain locations.

Locating new industrial facilities is one of the most imperative and time consuming to achieve by the decision makers, because it is going to be a planned decision including irrevocable distribution of the organization's capital [21]. Hence, gathering relevant information allows the formulation of some likely industrial sites that can be clustered, and gradually narrowed down choices by evaluating certain criteria through numerous iterations. In this kind of situation, the customer is familiar with a specific number of the available locations to enable them identify those groups (sites) that meets the selection criteria of the decision makers. Subsequently, after information gathering on specific sites, what is left is forming a group of sites that are involved in the shortlist meeting the selection criteria, after which the decision makers selects one of the sites [22]. According to Zelenovic (2003) ${ }^{[23]}$, the site selection process includes:

a) Identifying a group of influential criteria related to the site selection.

b) Forecasting and assessing the degree of their impacts in time and space 
c) Assessment of likely alternatives of solutions and selection of best alternative.

\section{Methodology}

\subsection{Data Collection}

An extensive literature and theories reviews on selecting suitable industrial sites was carried out. This has enabled the identification of of ten industrial site selection criteria. However, in the course of piloting the questionnaire, the criteria were narrowed down to six as the most important criteria in the case study DMA and data availabilility. These criteria were addressed to respondents to determine their degree of preference in influencing the suitability selection of industrial sites in the study area of Dammam Metropolitan Area, Kingdom of Saudi Arabia. Experts-based AHP questionnaire was designed based on the Saaty's scale of preference. Series of discussions with experts involved in Urban and Regional Planning, Environmental and Civil Engineering, Land Surveying etc. were held. The respondents were experts in the aforementioned fields with the academic ranks of Professors, Associate Professors, Assistant Professors, and Engineers. They have a depth of experience in research and practice with MOMRA and related municipalities around the Kingdom. In designing the questionnaire, an introduction containing the aim of the study was clearly written to give the respondents an insight on how to go about responding to the questions. The questionnaire went through series of pilot studies. This is to correct ambiguities; check wording to ensure that respondents understood the questions in the contexts that the researcher meant it to be. A pilot survey is viewed as a prerequisite to collect meaningful data for a research. According to Bell (2001), a pilot study, is "getting the bugs out of the instruments (questionnaire) so that the experts will experience no difficulties in completing the questionnaire ${ }^{[24]}$. Total number of 8 questionnaires was piloted before producing the final corrected version. During the pilot survey, things like narrowing down the number of criteria from 10 to 6 was deliberated and rephrasing some of the criteria to suite the goal of the study carried out. Thus after the pilot study, total of 16 questionnaires were distributed, where only 12 were retrieved and used. Since it is an experts-based questionnaire, a large sample size is not necessary; though, considering a reasonable number of respondents is meant to avoid bias in the calculation of the experts' judgments [25], otherwise according to Saaty (2009), a judgment from a single expert suffices ${ }^{[26]}$. The development of the questionnaire was done in such a way that each question was clearly phrased to avoid ambiguity and checked for expression, objectivity and relevance to the problem being investigated. The respondents were requested based on their experience to kindly tick the degree of preference or importance of each of the identified criteria for selecting a suitable industrial site(s) on a 1-9 Saaty's scale as shown in Table 2 . The criteria used in this study are present in Table1.

\section{Table 1. Site Selection Criteria.}

\begin{tabular}{|c|c|}
\hline Highways & $\begin{array}{l}\text { Approximately } 75 \% \text { of the industrial activities } \\
\text { are done on the highways. For this reason, } \\
\text { highways are given more significance than } \\
\text { other types of transportation network [27]. } \\
\text { Therefore, all roads as well as areas within the } \\
\text { distance of } 1500 \mathrm{~m} \text { are considered } \\
\text { inappropriate. }\end{array}$ \\
\hline $\begin{array}{l}\text { Railway } \\
\text { lines }\end{array}$ & $\begin{array}{l}\text { Railway lines are equally important as they } \\
\text { are used in some places for industrial } \\
\text { shipments. So, railway lines are given equal or } \\
\text { less priority to other mode of transportation } \\
\text { [27]. Distance of at least } 100 \mathrm{~m}-500 \mathrm{~m} \text { is } \\
\text { recommended when considered to be less } \\
\text { preferable. }\end{array}$ \\
\hline Airport & $\begin{array}{l}\text { In most cases, airport is considered to have a } \\
\text { reasonable proximity to an industry for } \\
\text { transportation of goods and services. } \\
\text { Therefore a distance of not less than } 1 \text { to } 3 \mathrm{~km} \\
\text { is recommended. }\end{array}$ \\
\hline Seaport & $\begin{array}{l}\text { Seaport is a very important factor to consider } \\
\text { when sitting an industrial for shipment of } \\
\text { industrial products. Seventy five percent or } \\
\text { more of the industrial activities are done via }\end{array}$ \\
\hline
\end{tabular}




\begin{tabular}{|l|l|}
\hline & $\begin{array}{l}\text { the sea. Therefore a distance of not more than } \\
1 \text { to } 2 \mathrm{~km} \text { is recommended for easy shipments. }\end{array}$ \\
\hline $\begin{array}{l}\text { Landfill } \\
\text { Sites }\end{array}$ & $\begin{array}{l}\text { Minimum distance of 2-5 km of landfill sites } \\
\text { is recommended from an industry, as some } \\
\text { industries do not tolerate any level of } \\
\text { pollution [28]. }\end{array}$ \\
\hline $\begin{array}{l}\text { Existing } \\
\text { industries }\end{array}$ & $\begin{array}{l}\text { Existing industries should meet the criteria } \\
\text { considered in this study to make its location } \\
\text { suitable. Similarly, the existing industries } \\
\text { should have a reasonable level of proximity to } \\
\text { other industries as well. }\end{array}$ \\
\hline
\end{tabular}

Source: Ref. ${ }^{[29]}$ (Modified by the authors)

\subsection{Multi-Criteria Decision Analysis}

Six criteria were used in identifying the most suitable industrial sites based on one of the techniques of the Multi-criteria Decision Analysis (MCDA). MCDA methods are used in calculating the relative important weights of criteria under investigation ${ }^{[30]}$. Decision problems are divided into smaller clear parts by the help of MCDA so as to analyze each part separately, and further integrate the parts in a rational way.

\section{a) Analytic Hierarchy Process}

The Analytic Hierarchy Process (AHP) is a mathematical modeling technique for multi-criteria decision making ${ }^{[6,31-34]}$. It was developed by Saaty, a mathematician in early 70s. The AHP method helps to specify numerical weights representing the relative importance of criteria (see also ${ }^{[6,7,9,12]}$. AHP allows both qualitative and quantitative approaches to solve complex decision problems. The technique structures/ decomposes problems into a hierarchy of elements or factors influencing a system by incorporating levels. In quantitative aspects, the AHP can prioritize a set of attributes and distinguish in general the most important factors from the less important ones. Pairwise comparison judgments are made with respect to the attributes of one level of hierarchy given the attribute of the next higher level of hierarchy (from the main criteria to the subcriteria). Analytical Hierarchy Process (AHP) can constructively be used for weights assignment to different criteria.Table 2 present the interpretations of the Saaty's 9 point scale of preference.

Table 2. Interpretation of the Saaty's scale of measurement.

\begin{tabular}{|c|c|c|}
\hline $\begin{array}{l}\text { Degree of } \\
\text { importance }\end{array}$ & Definition & Interpretation \\
\hline - & Equal importance & $\begin{array}{l}\text { Two element } \\
\text { making equal } \\
\text { contribution to the } \\
\text { goal }\end{array}$ \\
\hline 3 & $\begin{array}{l}\text { Somewhat more } \\
\text { important }\end{array}$ & $\begin{array}{l}\text { Moderate } \\
\text { importance of } \\
\text { element over the } \\
\text { other element }\end{array}$ \\
\hline 5 & $\begin{array}{l}\text { Much more } \\
\text { important }\end{array}$ & $\begin{array}{l}\text { Essential or strong } \\
\text { importance }\end{array}$ \\
\hline 7 & $\begin{array}{l}\text { Very much } \\
\text { important }\end{array}$ & $\begin{array}{l}\text { Very strong } \\
\text { importance }\end{array}$ \\
\hline 9 & $\begin{array}{l}\text { Extremely } \\
\text { important }\end{array}$ & Extreme importance \\
\hline $\begin{array}{c}\text { Scale, } 2.4,6 \\
\text { and } 8\end{array}$ & $\begin{array}{l}\text { Intermediate } \\
\text { values }\end{array}$ & $\begin{array}{l}\text { These are require } \\
\text { when comparison } \\
\text { between two } \\
\text { adjacent judgment } \\
\text { is needed }\end{array}$ \\
\hline Reciprocals & \multicolumn{2}{|c|}{$\begin{array}{l}\text { If } v \text { is the judgment value when } i \text { is } \\
\text { compared to } j \text {, then } 1 / v \text { is the judgment } \\
\text { value when } j \text { is compared to } i \text {. }\end{array}$} \\
\hline
\end{tabular}

Source: Ref. ${ }^{[35]}$.

The aggregation of the experts' preferences was calculated using a Geometric Mean method as shown below:

Geometric Means $=\left(\left(\mathrm{X}_{1}\right)\left(\mathrm{X}_{2}\right)\left(\mathrm{X}_{3}\right) \ldots\left(\mathrm{X}_{\mathrm{N}}\right)\right)^{1 / \mathrm{N}}$ : Where:

$\mathrm{X}=$ Individual score; and $\mathrm{N}=$ Sample size (Number of scores). Experts' preferences helped in performing the pairwise comparison matrix.

i) Weights Assignment.

Pairwise comparison matrix is used in calculating the weights of the criterions. This allows the comparison of two criteria at a time in accordance with their degree of importance in selecting the most suitable industrial sites in DMA. Matrixes of pairwise comparisons of the criterions were produced based on the priority ratings assigned by the experts. However, the pairwise comparisons of all the 
criteria under investigation are considered as the inputs, whereas the priority weights calculated are the outputs. The weights were further normalized and the normalized values of the eigenvector are used as the final outputs. The weights of the factors are generated based on the steps described by Malczewski (1999) [36].

\section{Results and Discussion}

\subsection{Pairwise Comparisons of the Criteria}

Multi-Criteria Decision Analysis (MCDA) is said to emerged at the beginning of $60 \mathrm{~s}$. Considerable number of MCDA experts' considered their profession to primarily stem from the early study on goal programming and study of Simon in $1977^{\text {[37]. }}$ A framework for evaluating decision making was proposed by Simon by differentiating between the intelligence, design, along with selection stages. MCDA methods are mathematical algorithms that define suitability of a specific result based on the input criteria, calculated weights along with other mathematical or logical means of generating trade-offs when conflict arises. Values from 1 to 9 were assigned to each criterion by the experts to reflect their relative importance. The findings of the study are as follows:

Where:

$\mathrm{C} 1=$ Highways

C2 $=$ Landfill Sites

C3 = Airport

$\mathrm{C} 4=$ Railway lines

$\mathrm{C} 5=$ Existing industries

C6 $=$ Seaport

Table 3 presents the priories given by the experts using typical pairwise comparisons of the criterions as well as the criteria weightings. Reciprocal matrices were assigned in comparing each set of pairs with regard to the criteria's degrees of significance in selecting suitable sites for industrial sites in DMA. For example, as presented in Table 3, C1 was scored 4.0 while compared with $\mathrm{C} 2$; and the reciprocal of 4.0 was scored to $\mathrm{C} 2$, which is 0.25 . Subsequently, the aforesaid process was employed throughout the rest of the comparisons. The experts' priorities in each column in Table 3 were summed up to produce a column total. Thus, each of the column value was then divided by its column total to compute the normalized matrix. The normalized matrix was summed up to give 1 or $100 \%$ in each column total of the normalized matrix. Finally, the rows of the normalized matrix were individually summed up and divided by the number of criteria to get the criteria weights. The expert's priorities were further revisited in order to check the degree of inconsistency in the rankings presented in Table 3. Thus, the priorities were individually multiplied by the weights as shown in Table 4 . The row total of each individual row of the aforementioned multiplication outputs was calculated and divided again by the weights. Moreover, the equation (1) came up with the consistency vector which was averaged to get $\lambda$ value. The $\lambda$ value was used in calculating the Consistency Index

$$
\{\text { Consist }\}=\left\{W_{S}\right\} \bullet\left\{\frac{1}{W}\right\}
$$

The Consistency Index (CI) was calculated using the equation below:

$$
\mathrm{CI}=\frac{\lambda-n}{n-1}
$$

Equation (2)

Where:

$\mathrm{n}=$ number of criteria (i.e. 6);

$\lambda=$ average value of the consistency vector determined above.

$\lambda=6.21+5.60+5.90+6.21+6.25+6.05=$ $36.21 / 6=6.03$. 
Therefore:

$\mathrm{CI}=36.21 / 6-1=0.01$

Lastly is calculating the Consistency Ratio (CR) to check whether the weights are acceptable or not. The rule in calculating a CR is that, a CR less than or equal to 0.1 is acceptable, that means the level of the inconsistencies is negligible; while a CR greater than 0.1 is not acceptable, in other words the result of the weights should be rejected. Therefore, the priorities should be revisited to check and rectify the inconsistencies. The Consistency Ratio is calculated using equation (3).

$$
\mathrm{CR}=\frac{C I}{R I}
$$

Equation (3)

Where:

$\mathrm{RI}=$ random inconsistency index whose value depends on the number (n) of factors being compared; for $\mathrm{n}=6, \mathrm{RI}=1.24$ as shown in Table $5^{[34]}$.

Table 3. Experts priority and weights calculation.

\begin{tabular}{|c|c|c|c|c|c|c|c|c|c|c|c|c|c|}
\hline \multicolumn{9}{|c|}{ Stage 1 } & \multicolumn{1}{c|}{ Stage 2 } \\
\hline & C1 & C2 & C3 & C4 & C5 & C6 & C1 & C2 & C3 & C4 & C5 & C6 & Weights \\
\hline C1 & 1.00 & 4.00 & 4.00 & 2.00 & 0.50 & 4.00 & 0.40 & 0.24 & 0.30 & 0.32 & 0.18 & 0.34 & 0.30 \\
\hline C2 & 0.25 & 1.00 & 0.50 & 0.33 & 0.25 & 0.33 & 0.10 & 0.06 & 0.04 & 0.05 & 0.09 & 0.03 & 0.06 \\
\hline C3 & 0.25 & 2.00 & 1.00 & 0.50 & 0.25 & 0.50 & 0.10 & 0.12 & 0.07 & 0.08 & 0.09 & 0.04 & 0.08 \\
\hline C4 & 0.50 & 3.00 & 2.00 & 1.00 & 0.50 & 3.00 & 0.20 & 0.18 & 0.15 & 0.16 & 0.18 & 0.25 & 0.19 \\
\hline C5 & 0.25 & 4.00 & 4.00 & 2.00 & 1.00 & 3.00 & 0.10 & 0.24 & 0.30 & 0.32 & 0.35 & 0.25 & 0.26 \\
\hline C6 & 0.25 & 3.00 & 2.00 & 0.33 & 0.33 & 1.00 & 0.10 & 0.18 & 0.15 & 0.05 & 0.12 & 0.08 & 0.11 \\
\hline SUM & 2.50 & 17.00 & 13.50 & 6.17 & 2.83 & 11.83 & 1.00 & 1.00 & 1.00 & 1.00 & 1.00 & 1.00 & 1.00 \\
\hline
\end{tabular}

Table 4. Consistency Ratio (CR) Calculation.

\begin{tabular}{|l|l|l|l|l|l|l|}
\hline $\mathrm{C} 1$ & 1.00 & 4.00 & 4.00 & 2.00 & 0.50 & 4.00 \\
\hline $\mathrm{C} 2$ & 0.25 & 1.00 & 0.50 & 0.33 & 0.25 & 0.33 \\
\hline $\mathrm{C} 3$ & 0.25 & 2.00 & 1.00 & 0.50 & 0.25 & 0.50 \\
\hline C4 & 0.50 & 3.00 & 2.00 & 1.00 & 0.50 & 3.00 \\
\hline C5 & 0.25 & 4.00 & 4.00 & 2.00 & 1.00 & 3.00 \\
\hline C6 & 0.25 & 3.00 & 2.00 & 0.33 & 0.33 & 1.00 \\
\hline
\end{tabular}

\begin{tabular}{|c|c|c|c|c|c|c|c|c|c|c|c|}
\hline & 0.30 & 0.06 & 0.08 & 0.19 & 0.26 & 0.11 & & \multirow{9}{*}{$\div$} & & & \\
\hline & \multicolumn{6}{|c|}{$=$} & SUM1 & & & & \\
\hline $\mathrm{C} 1$ & 0.30 & 0.24 & 0.34 & 0.37 & 0.13 & 0.45 & 1.83 & & 0.30 & \multirow{6}{*}{$=$} & 6.21 \\
\hline $\mathrm{C} 2$ & 0.07 & 0.06 & 0.04 & 0.06 & 0.07 & 0.04 & 0.34 & & 0.06 & & 5.60 \\
\hline $\mathrm{C} 3$ & 0.07 & 0.12 & 0.08 & 0.09 & 0.07 & 0.06 & 0.49 & & 0.08 & & 5.90 \\
\hline $\mathrm{C} 4$ & 0.15 & 0.18 & 0.17 & 0.19 & 0.13 & 0.34 & 1.16 & & 0.19 & & 6.21 \\
\hline $\mathrm{C} 5$ & 0.07 & 0.24 & 0.34 & 0.37 & 0.26 & 0.34 & 1.63 & & 0.26 & & 6.25 \\
\hline C6 & 0.07 & 0.18 & 0.17 & 0.06 & 0.09 & 0.11 & 0.69 & & 0.11 & & 6.05 \\
\hline & & & & & & & & & & SUM2 & 36.21 \\
\hline
\end{tabular}

$\lambda=\mathrm{SUM} 2 / \mathrm{n}=6.03$ 


$$
\mathrm{CI}=\frac{\lambda-\mathrm{n}}{\mathrm{n}-1}=0.01
$$

CONSISTENCY RATIO (CR)

Table 5. Random Inconsistency index.

$$
\begin{aligned}
& \mathrm{CR}=\begin{array}{l|c|c|c|c|c|c|c|c|c|}
\mathrm{CI} \\
\hline \mathrm{RI}
\end{array} \\
& \mathrm{CR}=\begin{array}{l}
0.01 \\
1.24
\end{array}=0.01 \quad \mathrm{CR}<0.1: \text { REASONABLE }
\end{aligned}
$$

Using the CR equation above,

$$
\mathrm{CR}=\frac{0.01}{1.24}=0.01
$$

Therefore, as $0.01<0.1$, it shows that there is a realistic degree of consistency in the pairwise comparison and as a result, the weights $0.30,0.26,0.19,0.11,0.08$ and 0.06 can be assigned to highways, existing industries, railway lines, seaport, airport, and landfill sites respectively.

As seen from the findings of the study, proximity to highways got the highest score with 0.30 , followed by proximity to existing industries with 0.26 , proximity to railway lines with 0.19 , and proximity to seaports with 0.11 . These findings corresponded to what is obtainable in DMA. In DMA, most of the industries use the highways, existing industries, railway lines, and seaports for their shipments of goods and services. Therefore, applying the criteria used in this study to evaluate the existing industries in DMA will aid the decision makers in taking appropriate risk management measures and in selecting the most suitable site(s) for industrial location.

\subsection{AHP Model-based Evaluation of the Existing Industries in DMA}

The AHP mathematical model developed in this study is used in evaluating the locations of the existing industries in Dammam Metropolitan Area shown in Fig. 2.

Hence, assessment of the existing industries was done by assigning degrees of suitability from most appropriate to not appropriate. As illustrated in Table 6, the new industrial site proposed and approved by the government (Site 4 in Fig. 2) is lacking the two of the most important criteria; proximity to highways and seaports, that is why it is highly recommended to ensure that highways are fully developed, as well as proper connections to the seaports should be provided to satisfy the industrial site selection criteria investigated in this study. The table aslo revealed that, the existing industrial estate (Site 2) was less approporiate than the newely proposed and approved one (Site 4) in terms of proximity to other industrial estates, airport, seaport and landfill sites. Based on these findings, it is highly recommended to relocate or transfer it to Site 4. In addition to that, Site 1 is also recommended to be relocated to Site 4 , as shown in Table 6, it is less appropriate in terms of proximity to seaport and landfill site. Finally, Site 2 is situated in the most approporiate location based on 4 of the six evaluation criteria as shown in Table 6 . 
Table 6. Evaluation of existing industries.

\begin{tabular}{|c|c|c|c|c|c|c|c|}
\hline \multirow{2}{*}{$\begin{array}{l}\mathrm{S} / \\
\mathrm{N}\end{array}$} & \multirow[b]{2}{*}{$\begin{array}{c}\text { Names of } \\
\text { existing } \\
\text { industrial areas }\end{array}$} & \multicolumn{6}{|c|}{ Evaluation criteria } \\
\hline & & $\begin{array}{l}\text { Proximity to } \\
\text { highways }\end{array}$ & $\begin{array}{l}\text { Proximity to } \\
\text { other existing } \\
\text { industries }\end{array}$ & $\begin{array}{l}\text { Proximity to } \\
\text { railway lines }\end{array}$ & $\begin{array}{l}\text { Proximity to } \\
\text { seaport }\end{array}$ & $\begin{array}{l}\text { Proximity to } \\
\text { airport }\end{array}$ & $\begin{array}{l}\text { Proximity to } \\
\text { landfill sites }\end{array}$ \\
\hline 1 & $\begin{array}{c}\text { First Industrial } \\
\text { Area }\end{array}$ & $\begin{array}{l}\text { Most } \\
\text { appropriate }\end{array}$ & $\begin{array}{l}\text { Moderate } \\
\text { appropriate }\end{array}$ & Appropriate & $\begin{array}{l}\text { Most } \\
\text { appropriate }\end{array}$ & $\begin{array}{l}\text { Least } \\
\text { appropriate }\end{array}$ & $\begin{array}{l}\text { Less } \\
\text { appropriate }\end{array}$ \\
\hline 2 & Al-Khadriya & $\begin{array}{l}\text { Most } \\
\text { appropriate }\end{array}$ & $\begin{array}{l}\text { Less } \\
\text { appropriate }\end{array}$ & $\begin{array}{l}\text { Least } \\
\text { appropriate }\end{array}$ & Appropriate & $\begin{array}{l}\text { Less } \\
\text { appropriate }\end{array}$ & $\begin{array}{l}\text { Less } \\
\text { appropriate }\end{array}$ \\
\hline 3 & $\begin{array}{c}\text { Second } \\
\text { Industrial area }\end{array}$ & $\begin{array}{l}\text { Most } \\
\text { appropriate }\end{array}$ & $\begin{array}{l}\text { Most } \\
\text { appropriate }\end{array}$ & $\begin{array}{l}\text { Most } \\
\text { appropriate }\end{array}$ & $\begin{array}{l}\text { Less } \\
\text { appropriate }\end{array}$ & Appropriate & $\begin{array}{l}\text { Most } \\
\text { appropriate }\end{array}$ \\
\hline 4 & $\begin{array}{c}\text { Approved } \\
\text { Industrial Area }\end{array}$ & $\begin{array}{l}\text { Less } \\
\text { appropriate }\end{array}$ & $\begin{array}{l}\text { Less } \\
\text { appropriate }\end{array}$ & $\begin{array}{l}\text { Most } \\
\text { appropriate }\end{array}$ & $\begin{array}{l}\text { Not } \\
\text { appropriate }\end{array}$ & $\begin{array}{l}\text { Most } \\
\text { appropriate }\end{array}$ & $\begin{array}{l}\text { Most } \\
\text { appropriate }\end{array}$ \\
\hline
\end{tabular}

Source: Authors.

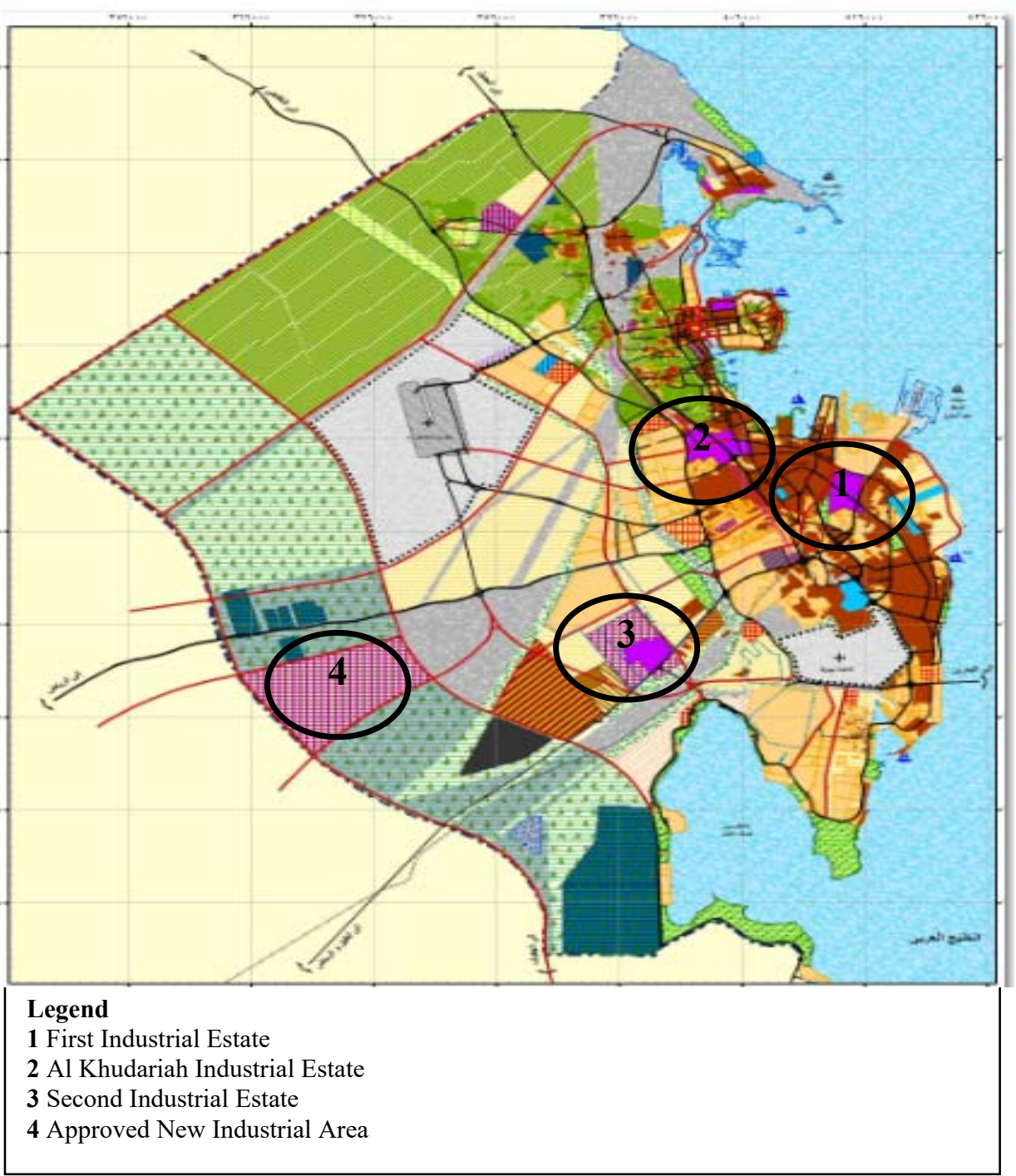

Fig. 2. Structural Plan for Dammam Metropolitan Area, Ref. ${ }^{[29] .}$ 


\section{Conclusion and Recommendations}

Site selection for industrial development is in reality a spatial problem that requires spatial decision making to be made based on geographically related criteria. The findings in this study impliy that, the application of AHP mathematical model in evaluating the degree of importance of the evaluation criteria employed herein is reliable. The AHP techniques helped the authors in identifying the most important criteria. In validating the findings of the study, weights calculated from the AHP were applied on the existing as well as the newly approved industrial areas within Dammam Metropolitan Area. The application of these criteria assisted in reaching a conclusion that, some of the existing industries should be relocated and the newly approved industrial site should be improved in terms of accessibility (road networks).

\section{Future Research}

Future research will focus on further exploration of appropriate geographical data of the criteria used in this study. This is to enable the integration of the AHP model developed herein with Geographic Information System (GIS). The integration of AHP with GIS will enable the authors to carry out a spatial analysis, to come up with the land suitability model for industrial sites location. The land suitability model will provide the decision makers with visual information about the most suitable locations to site an industry, so as to make a better and more efficient decision.

\section{References}

[1] Rikalovic, A., Cosic, I. and Laz-arevic, D. (2014)." GIS Based Multi-Criteria Analysis for Industrial Site Selection". Procedia Engineering, 69: 1054 - 1063.

[2] Keeney, R.L. (1980), Siting Energy Facilities. New York: Academic Press.

[3] Williams, E.A. and Massa, A.K. (1983). Siting of Major Facilities: A Practical Approach. New York: McGrawHill Inc.
[4] Badri, M, A. (2007). Dimensions of Industrial Location Factors: Review and Exploration, Jornal of Business and Public Affairs, 1(2): 1-26.

[5] Eldrandaly, K. (2013), Developing a GIS-Based MCE Site Selection Tool in ArcGIS Using COM Technology, The International Arab Journal of Information Technology, 10(3) May: 276-282.

[6] Chen, D. C., Chen, P. C., Lee, Y. C., You, S. U. and Jao, H. C. (2011). Using an analytic hierarchy process to develop competencies on mould product creativity for vocational college students. World Transactions on Engineering and Technology Education (WIETE), 9(1): 54-59.

[7] Emmanouloudis, D., Myronidis, D. and Ioannou, K. (2008). Assessment of Flood Risk in Thasos Island with the Combined Use of Multi-criteria Analysis AHP and Geographical Information System. Innovative Applications of Informatics in Agriculture and Environment, 2:103-115 ESRI.

[8] Jun, D. K., Chung, C S., Han, K S.M. and Yeon, S. H. (2005). Development of an Assessment Model Using AHP Technique for Railroad Projects Experiencing Severe Conflicts in Korea. In: Proceedings of the Eastern Asia Society for Transportation Studies, 5: 2260 - 2274.

[9] Meyer, V., Scheuer S. and Haase, D. (2009). A MultiCriteria Approach for Flood Risk Mapping Exemplified at the Mulde River, Germany. Natural Hazards, 48: 17-39.

[10] Salem, M. S. M. (2010). An Application of the Analytic Hierarchy Process to Determine Benchmarking Criteria for Manufacturing Organisations, International Journal of Trade, Economics and Finance, 1(1) June: 93 - 102.

[11] Scheuer, S., Haase, D. and Meyer, V. (2011). Exploring Multi-Criteria Flood Vulnerability by Integrating Economic, Social and Ecological Dimensions of Flood Risk and Coping Capacity: From a Starting Point View Towards An End Point View Of Vulnerability. Natural Hazards, 58(2): 731-751.

[12] Sinha, R., Bapalu, G., Singh, L. and Rath, B. (2008). Flood Risk Analysis in the Kosi River Basin, North Bihar Using Multi-Parametric Approach of Analytical Hierarchy Process (AHP). Journal of Indian Society of Remote Sensing, 36: 335-349.

[13] Wang, Y., Li, Z., Tang, Z. and Zeng, G. (2011). A GISbased Spatial Multi-Criteria Approach for Flood Risk Assessment in the Dongting Lake Region, Hunan, Central China. Water Resource Management, 25: 3465-3484.

[14] Wong, J.K. and Li, H. (2007). Application of the Analytic Hierarchy Process (AHP) in Multi-Criteria Analysis of the Selection of Intelligent Building Systems. Building and Environment, doi:10.1016/j.buildenv.2006.11.019.

[15] Ryu, S. Y. (2005). Development of Usability Questionnaires for Electronic Mobile Products and Decision Making Methods. Unpublished Ph.D. Thesis, 
Virginia Polytechnic Institute and State University.

[16] Dai, F.C., Lee, C.F. and Zhang, X.H. (2001). Assessment of Landslide Susceptibility on the Natural Terrain of Lantau Island, Hong Kong. Environmental Geology, 61: 257-271.

[17] Ayalew, L., Yamagishi, H. and Ugawa, N. (2004). Landslide Susceptibility Mapping Using GIS-based Weighted Linear Combination, The Case in Tsugawa Area of Agano River, Niigata Prefecture, Japan. Landslides, 1: 73-81.

[18] Komac, M. (2006). A Landslide Susceptibility Model Using the Analytical Hierarchy Process Method and Multivariate Statistics in Perialpine, Slovenia. Geomorphology, 74(1-4): 17-28.

[19] Aboukorin, A, A. and Al-Shihri, F. S. (2015). Rapid Urbanization and Sustainability in Saudi Arabia: The Case of Dammam Metropolitan Area. Journal of Sustainable Development, 8 (9): 52-65.

[20] Florida, R. (2002). The Rise of the Creative Class. The Washington Monthly, pp: 15-25.

[21] Bhatnagar, R. and Sohal, A. S. (2005). Supply chain competitiveness: measuring the impact of location factors, uncertainty and manufacturing practices. Technovation, 25(5): 443-456.

[22] Kotler, P.J., Haider, D.H. and Rein, I. (1993) Marketing Places: Attracting Investment, Industry and Tourism to Cities, States and Nations, New York, Ltd: Free Press.

[23] Zelenovic, D. (2003) The Design of Production Systems: Book, Faculty of Technical, Novi Sad.

[24] Bell, J. (2001). Doing Your Research Projects: A Guide for the First Time Researchers in Education and Social Science $\left(4^{\text {th }}\right.$ ed.). Buckingham: Open University Press.

[25] Ishizaka, A. and Labib, A. (2011). Review of the Main Developments in the Analytic Hierarchy Process. Expert Systems with Applications, 38(11): 14336-14345.

[26] Saaty, T. L. and Sagir, M. (2009). Extending the Measurement of Tangibles to Intangibles. International Journal of Information Technology and Decision Making, 8(1): 7-27.

[27] Agrawal, M.L. and Dikshit, A.K. (2002). "Significance of Spatial Data and GIS for Environmental Impact Assessment of Highway Projects Significance of Spatial Data and GIS for Environmental Impact Projects", $J$.
Indian Cartographer, pp. 262-266.

[28] Alanbari, M. A., Al-Ansari, N., Hadeel, K. J. and Sven, K. (2014)." Al-MseiabQadaa Landfill Site Selection Using GIS and Multi-criteria Decision Analysis". Engineering, 6: 526-549.

[29] Alzamili, H. H., El-Mewafi, M., Beshr, A. M. and Awad A. (2015). GIS Based Multi Criteria Dicesion Analysis for Industrial Site Selection in Al-Nasiriyah City in Iraq. International Journal of Scientific \& Engineering Research, 6(7) July: 1330-1337.

[30] Feizizadeh, B., Roodposhtib, M. S., Jankowskic, P. and Blaschke, T. (2014). A GIS-Based Extended Fuzzy MultiCriteria Evaluation for Landslide Susceptibility Mapping. Vol. 73, December 2014, pp: 208-221.

[31] Cheng, E. W. L. and Li, H. (2001). Analytic Hierarchy Process: An Approach to Determine Measures for Business Performance. Measuring Business Excellence, 5(3): 30-37.

[32] Coyle, G. (2004). The Analytic Hierarchy Process, Practical Strategy. Open Access Material, AHP.

[33] Modarres, M., Sadi-Nezhad, S. and Arabi, F. (2010). Fuzzy Analytical Hierarchy Process Using Preference Ratio: A Case Study for Selecting Management Short Course in a Business School. International Journal of Industrial Engineering Computations, 1(2): 173-184.

[34] Saaty, T. L. (1980). The Analytic Hierarchy Process: Planning, Priority Setting and Resource Allocation. McGraw-Hill, New York.

[34] Lawal, D. U., Matori, A., Yusof, K. W., Hashim, A. M., Aminu, M., Sabri, S., Balogun, A., Chandio, I. A. and Mokhtar, M. R. M. (2013). Group-based Decision Support for Flood Hazard Forecasting: A Geospatial Technologybased Group Analytic Hierarchy Process Approach. Research Journal of Applied Sciences, Engineering and Technology, 7(23): 4838-4850, 2014.

[34] Malczewski, J. (1999). GIS and Multi-Criteria Decision Analysis. John Wiley and Sons, Inc. United States of America, pp: 177-192.

[34] Drobne, S. and Lisec, A. (2009). Multi-attribute decision analysis in GIS: Weighted linear combination and ordered weighted averaging, Nature, 4(26): 28. 


\section{نموذج اختيار المواقع الصناعية نحو تتمية أكثر استدامة لحاضرة الدمام: عملية التسلسل الهرمي التحليلية المعتمدة فائز سعد الثهري و عمر دانو لاوال قسم التخطيط الحضري والإقلييه، كلية العدارة والتخطيط، جامعة الدمام، المملكة العربية السعودية} fshihri@uod.edu.sa

المستخلص. اختيار الموقع الصناعي هو عملية اختيار المواقع الأكثر مناسبة، والتي تفي بالمتطلبات التي تمليها مجموعة من معايير الاختيار ؛ ويعتبر اختيار أحد المواقع لصناعة ما استثمار ضخم وطويل الأجل، ولذلك يصبح من الضروري تحري الدقة

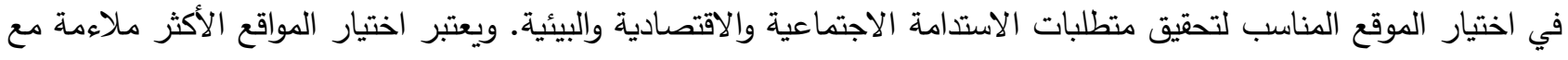
تلك المتطلبات أحد أهم الأهداف الرئيسة لعملية اختيار المواقع الصناعية. ولوحظ أن غالبية البيانات المستخدمة من قبل صناع القرار في اختيار المواقع الصناعية مرتبطة جغرافيا، مما يدل على أن عملية اختيار الموقع الصناعي هي في الأساس قضية اتخاذ قرار مكاني. لذلك تستخدم هذه الدراسة نموذج عملية التسلسل الهرمي التحليلية (AHP) لتقييم مدى ملاعمة المواقع للصناعات القائمة بحاضرة الدمام استتادًا إلى عدد من معايير اتخاذ القرار المستخدمة في اختيار أنسب المواقع الصناعية. وقد تم حساب الأوزان والأولوية بعد ترتيب كل معيار باستخدام "مقياس SAATY" ذي التسع نقاط، حسب تقدير الأفضلية من قبل الخبراء المشاركين في الاستبيان. وتم حساب الأوزان ومعالجتها رياضيًّا باستخدام نموذج التسلسل الهرمي التحليلي. واستخدمت نتائج الاستبيان لتقييم المواقع الصناعية القائمة والمعتمدة في حاضرة الدمام، ومن ثم توصلت الدراسة إلى نتائج مهمة وتوصيات فيما يتعلق بالمواقع الصناعية القائمة والمعتمدة في الحاضرة. كلمات دفتاحية: تحليل الصلاحية، اختيار المواقع الصناعية، عملية التسلسل الهرمي التحليلية، الاستدامة الحضرية، حاضرة الدمام. 